\title{
PROCEEDINGS OF THE ASSOCIATION OF INDUSTRIAL MEDICAL OFFICERS SCOTTISH GROUP
}

Minutes of the Annual General Meeting, held on Wednesday, October 30, 1946, at the Institute of Hygiene, University of Glasgow.

Dr. D. M. Watson, Medical Officer, Messrs. Stewarts and Lloyds, Ltd., tcok the chair. In opening the meeting, he welcomed Dr. Meiklejohn and Dr. Rogen, Reader and Lecturer in Industrial Hygiene at the University of Glasgow.

The minutes of the last meeting were read and adopted.

The secretary intimated that he had received no nominations from members of the group for the various offices to be filled at this meeting. Dr. Meiland intimated his desire to resign from the Executive Committee, and this was accepted with regret. Dr. Meiland, however, assured the group that he would continue to give his support. The following members were elected: Hon. Secretary, Dr. George Buchanan; Hon. Treasurer, Dr. Edward Collier; Executive Committee, the Chairman, Hon. Treasurer, Hon. Secretary, Dr. H. M. Roberts - (ex officio), and Dr. Grace Smith, Dr. D. G. Robertson, Dr. J. Fleming, Dr. J. B. Lynch, Dr. J. W. Henderson, and Dr. A. S. Rogen.
The Hon. Treasurer read his financial statement for the year. The meeting then dealt with a letter from the Hon. Secretary of the Association, Dr. Pringle, who requested that consideration be given to the possibility of holding the May meeting of the Association in Glasgow. After considerable discussion it was agreed that this would not be practicable, but it was thought it would be possible to do something in 1948. The Secretary (Scottish Group) was instructed to write Dr. Pringle and inform him of the meeting's conclusions.

Arrangements were made to hold the following meetings during 1946-47: Wednesday, Dec. 11, 1946, at 3 p.m., Institute of Hygiene, Glasgow University, symposium on industrial health, by Professor T. Ferguson and assistants; Wednesday, Feb. 5, 1947, at 3 p.m., the Skin Department, Royal Infirmary, Glasgow; March, 1947 (date to be arranged), Mr. Barnes, Orthopaedic Surgeon, Western Infirmary, Glasgow; May, 1947 (date to be arranged), Members' Day.

The meeting then went on to consider measures for the improvement of attendances at group meetings and liaison with the Industrial Health Department of the Institute of Hygiene. 
services as a whole. Ten years ago, however, the Report of the Committee on Scottish Health Service recognized that success or failure in either service had a direct bearing on the other, and the Committee felt that industrial health should be treated not as an isolated entity, but as an essential and integral part of national health policy. The Committee recommended that there should be closer liaison arrangements for the pooling of knowledge and for joint action on common problems, and that, for instance, the opportunities presented by the medical examination of young entrants into industry should be more fully utilized. It was true that much had been done during the past ten years to place the examination of young entrants to industry on a better footing, and the extension of school age, with statutory requirements that young people should continue parttime post-elementary education, offered scope for the extension of health supervision of young industrial workers. Quite likely these young people would be subject to school medical examination up to the age of 18 , and at least four medical agencies would be interested in many of them-the school doctor, the industrial medical officer, the examining surgeon, and the family doctor. It was clearly important to secure an enlightened integration of effort and to secure the development of vocational guidance necessary to diminish the prevalent wastage of manpower and the dead-ending that got so many youngsters away to a bad start in life.

The Disabled Persons (Employment) Act, good as were its intentions, had raised many awkward administrative issues. It was already clear that many of the most difficult problems in resettlement were concerned with medical rather than surgical disabilities, and that nearly all were connected with social problems. Prof. Ferguson felt that soon there must be a co-ordinated approach to the study of the health and industrial problems raised by cardiac disease, tuberculosis, and degenerative conditions generally.

Sooner or later it would become necessary to review the position of the industrial medical officer. Ought ${ }^{\prime}$ he to have any statutory authority? What should be his relation to the State Departments, to the new hospital system, to the new health centres, and to the new general practitioner? The scope of occupational medicine should be wide, including applied physiology, based on the recognition that for most folk congenial work under reasonable conditions is one of the best prescriptions for healthy living.

The Regulations for the Diploma in Industrial Health of the Royal College of Physicians demanded attendance at an introductory course in social medicine corresponding to the first three months of the new D.P.H. Course. The preliminary course was concerned with such things as the history of public health and public assistance; the existing functions of central and local health authorities and the structure of health services; the health problems of certain groups of the population; hospital services and resettlement; social security and the agencies for the relief of poverty and promotion of social welfare; the elements of social economics; the nature, sources and control of infections; environmental factors in relation to health; criteria of national wellbeing and the influence of social conditions on vital statistics; methods of health education, social surveys, and social case records; and the preparation of memoranda bearing on various aspects of the health of the people. Prof. Ferguson asked his listeners whether teaching along these lines was, in their opinion, likely to be of value to the industrial medical officer. Could they suggest any other broad subject-group that ought to be included, bearing in mind that the second six months of the course made provision for more detailed study of specific technical subjects? The aim in an introductory course of the type outlined must necessarily be to provide, on as broad a basis as possible, not only a working knowledge of existing social services, but also a cultural background against which more technical problems could be considered.

Then there was the question of research. Prof. Ferguson was sure that not nearly enough thought had been given to the impact of social factors on industrial health. Some work had been done, much of it under the auspices of the Industrial Health Research Board, on the relationship between social factors and outputnutritional factors, travelling time, sleep in relation to. working shifts, etc. And, following the 1931 census, the Registrar-General had studied the death-rates prevailing among different social classes of the population. But there were many problems about which we knew little. Why did people take up certain kinds of employment? How far was occupational drift influenced or compelled by social considerations ? How could we place successfully in industry the high-grade defective who, as war experience showed, was capable of useful physical or repetitive work? Could we not do more to help young people entering industry? Prof. Ferguson said it was hoped soon to begin a survey of the experience of young people leaving Glasgow schools at the age of 14. The survey, starting from the child's school record, would follow his experience over a period of four or five years and would take special cognisance of his difficulties-physical, economic, and in relation to work.

Dr. Meiklejohn concluded the symposium and the following were among the more important topics on which he commented:

1.-The present position and strength of medicine in industry as represented by full-time and part-time medical and nursing services. "No nurse should be employed in industry except under medical direction and supervision."

$$
\text { 2.-The future "Health Service" in industry. }
$$

3.-Great Britain a country of small factories, many of them "slums." Part-time M.O.s should be part of an integrated service directed by specialist industrial M.O.s

\section{4.-The doctor-patient relationship in industry.}

5.-A plea for a balanced objective judgment in the application of "new discoveries," e.g. mass radiography.

\section{CORRECTION}

On p. 76 of the January issue in the Proceedings of the Association of Industrial Medical Officers, Scottish Group, the name of Dr. J. M. Rogan was wrongly printed as A. S. Rogen. 